\title{
Adenosarcoma Pathologic Distant Metastasis TNM Finding v7
}

National Cancer Institute

\section{Source}

National Cancer Institute. Adenosarcoma Pathologic Distant Metastasis TNM Finding v7. NCI Thesaurus. Code C89626.

A pathologic finding about one or more characteristics of adenosarcoma, following the rules of the TNM AJCC V7 classification system as they pertain to distant metastases. There is no pathologic MO. (from AJCC 7th Ed.) 